\title{
Care to the person in a terminal process in the perception of the nursing students
}

\author{
0 cuidado à pessoa em processo de terminalidade na percepção de graduandos de \\ enfermagem
}

Atención a la persona en proceso terminal en la percepción de estudiantes de enfermería

Rudval Souza da Silva ${ }^{1}$, Claudia Cristina Souza Gribel Oliveira² ${ }^{2}$ Álvaro Pereira ${ }^{2}$, Juliana Bezerra do Amaral ${ }^{2}$

Objective: to know the experiences of the nursing students regarding the care to the person in a terminal process. Methods: a qualitative study with data collected through semi-structured interviews held with ten nursing students. Results: from the data analysis, two theme categories emerged: Feelings expressed facing the first contact with the patients in a terminal process and care to the patient in a terminal process: dichotomy between theory and practice. When experiencing the care to the person in the dying process, students have shown that the feeling of helplessness was the most striking, among others such as sadness, anguish and insecurity. Conclusion: the practices of care of the nursing team disagree with the academic discussions, denying the discourse that the nurse should be present with the patient, regardless of his clinical condition.

Descriptors: Nursing Care; Students, Nursing; Palliative Care; Critical Illness.

Objetivo: conhecer as experiências dos graduandos de enfermagem frente o cuidado à pessoa em processo de terminalidade. Métodos: estudo qualitativo com dados coletados por meio de entrevistas semiestruturadas, realizadas com dez estudantes de enfermagem. Resultados: da análise dos dados, emergiram duas categorias temáticas: Sentimentos expressos frente o primeiro contato com pacientes em processo de terminalidade e Cuidar do paciente em processo de terminalidade: dicotomia entre teoria e prática. Ao vivenciarem o cuidar à pessoa em processo de morrer, os estudantes demonstraram que o sentimento de impotência foi o mais marcante, dentre outros como tristeza, angústia e insegurança. Conclusão: as práticas de cuidados da equipe de enfermagem destoam das discussões acadêmicas, negando o discurso de que o enfermeiro deve se fazer presente junto ao paciente, independente da sua condição clínica.

Descritores: Cuidados de Enfermagem; Estudantes de Enfermagem; Cuidados Paliativos; Estado Terminal.

Objetivo: conocer las experiencias de estudiantes de enfermería delante de la atención a la persona en proceso terminal. Métodos: estudio cualitativo con datos recogidos a través de entrevistas semiestructuradas realizadas con diez estudiantes de enfermería. Resultados: del análisis de datos, surgieron dos categorías temáticas: Sentimientos expresados delante del primer contacto con pacientes en proceso terminales y Atención al paciente terminal: dicotomía entre teoría y práctica. Cuando experimentan la atención a la persona en proceso de la muerte, los estudiantes han demostrado que el sentimiento de impotencia fue el más llamativo, entre otros, como tristeza, ansiedad e inseguridad. Conclusión: prácticas de atención de enfermería del personal están lejos de las discusiones académicas, negando el discurso de que el enfermero debe estar presente con el paciente, independientemente de su condición clínica.

Descriptores: Atención de Enfermería; Estudiantes de Enfermería; Cuidados Paliativos; Enfermedad Crítica.

\footnotetext{
${ }^{1}$ Universidade do Estado da Bahia - Campus VII. Senhor do Bonfim, BA, Brazil.

${ }^{2}$ Universidade Federal da Bahia. Salvador, BA, Brazil. 


\section{Introduction}

Despite the constant technological evolution regarding the care of human health, during the professional practice, the nursing team is confronted daily with the phenomenon of death ${ }^{(1)}$. Although this is considered a biological and social event, modern society understands this phenomenon as forbidden, so the need to provide moments of discussions on the subject has been observed to better understand the process of human finitude ${ }^{(2)}$.

Facing death has been modified according to the process of evolution of civilization. In the early centuries of human history, death represented a moment of resignation. Thus, at the time when preparing the family members for mourning, the person who was dying, took advantage of this moment to accept his own death, so that this happened in a public ceremony, organized and shared by family members and friends as well as being experienced by the subject himself ${ }^{(3)}$.

With the advent of modernity, the process of dying and death were extirpated from the family environment and it became hidden and denied in everyday conversations. And when it comes to the context in which health professionals are inserted, the phenomenon of death started invoking feelings of helplessness and guilt, once the direction given to the training of professionals, almost exclusively aimed at "saving lives" and the "healing of diseases". Health professionals have had a very centered training on the disease, and little is said about death as part of the vital cycle, as if it were an opposition to life $\mathrm{e}^{(3-4)}$.

Understanding the paradox that permeates the dualism of life versus death, becomes an extremely important factor for the nursing team ${ }^{(4)}$. When providing care to the person in the process of dying and facing death, they are confronted with the difficulties facing death, therefore, become aware that they are not prepared for this confrontation ${ }^{(3-4)}$.

The existential dilemmas that permeate death are resulting from the conception of life of each person. The beliefs, values and experiences directly influence in the way of coping when we are exposed to a situation of $\operatorname{loss}^{(5)}$. From this perspective, it is perceived that there is a great need to prepare health professionals since graduation, to better cope with death, since, in their training they are often educated only to take care for the cure of the disease, with no guidance to positive coping facing the phenomenon of death and its inevitability.

From the nineteenth century on, death underwent a process of institutionalization and medicalization. The family setting where the death occurred, was replaced by hospital setting, away from the person who is dying and their family members and, as no one realizes the preparation of health professionals to deal with such situation, the idea of professional failure then emerges ${ }^{(3-4)}$.

Another issue that is hampering the relationship between health professionals and the phenomenon of death, is in the gap between these and the person who is dying, amid the technological apparatus that has kept away the health professionals from the practices of care with humanism and sensitivity. Thus, the existing conflicts facing the process of terminality have become increasingly exacerbated due to the weakening of the relationship between those who care and those who are taken of care of. In contemporary times, this bond has decreased considerably, leading the rationalization of care towards greater efficiency, making the technical knowledge overlap the relational and human care and ${ }^{(6-7)}$.

And when it comes to academic education, researches have shown that nursing students have demonstrated the need to receive continued support and have opportunities for reflection and discussion about their experiences during the practical activities and training courses on how to take care of patients in the process of terminal illness and how to face their fears and doubts before death ${ }^{(8)}$.

The moments of reflections and discussions are already considered as mandatory as soon as graduation begins because students need to be 
prepared to take care of those who are experiencing the process of dying and death ${ }^{(9)}$.

In this context, one can understand the need to discuss the academic preparation of future nurses on how these professionals should deal with situations involving the process of dying and death. It is assumed that empowering the students to cope with death as a natural phenomenon which needs care in order to preserve the dignity of the dying person and the elaboration of the process of mourning of the family members, could untie the idea of death as a failure and provide new nurses with the possibility of recognizing their limitations facing human care.

This study aimed at understanding the experiences of the nursing students facing the care to the person in a terminal process.

\section{Method}

It is a qualitative, exploratory and descriptive study, developed with nursing students in a public university in the city of Salvador, Bahia, Brazil, where in addition to being the locus of the development of the project of scientific initiation, it develops activities of curricular practices with the students in order to allow the experience of these in various health units, with varying levels of complexity as the units of emergencies and intensive care, enabling students to the experience the care of the person in the process of dying and facing death.

Ten nursing students participated as subjects of the study. Random sampling was used for the selection of participants in the study, data collection ended when they showed signs of saturation, that is, when there was no new information on the phenomenon under study. The study was held from July to October 2011.

For data collection, semi-structured interviews were used, held in a private venue, being recorded and later treated. The variables of interest were: age, sex, religion, the semester of the course and whether the participant had previous experience of dealing with the care of a person in the process of terminality. To guide the main objective of the research the following guiding questions were used: Have you ever had contact with patient in a terminal process? What was your experience in relation to the care developed by the nursing team to these patients?

Interviews were transcript and analyzed using the content analysis ${ }^{(10)}$, following the steps: (1) pre-analysis, through which the brief reading of the statements of participants took place; (2) the exploration of the material allowed the researchers to make clippings of the statements in the units of records, which were classified and coded, and finally, grouped by the convergence in units of meanings; and (3) the treatment of the results, the last phase of the analysis, which made it possible to aggregate and prioritize categories of greatest relevance to the subject matter to be discussed and interpreted in accordance with the theoretical framework.

From the processing of the results the following thematic categories emerged: 1) Feelings expressed facing the first contact with the patients in a terminal process 2) the care to the patient in a terminal process: dichotomy between theory and practice.

This study was approved by the Committee of Ethics in Research with Human beings of the Escola de Enfermagem of the Universidade Federal da Bahia, under legal opinion 22/2011. The participants signed the Informed Consent Form. In order to keep their anonymity, the subjects were identified by NS01, NS02 ... NS10.

\section{Results}

Among the ten participants in the study, the age range was from 22 to 27 years, two males and eight females. Concerning religion, four reported to have no religion, two were Protestant, three Catholic of which two reported to be non-practicing Catholics and one followed the spiritualist doctrine. Regarding the academic period one student was attending the seventh semester, five the eighth and four of 
them attended the tenth and last semester of the undergraduate course of nursing.

\section{Category 1 - Feelings expressed facing the first contact with patients in a terminal process}

Facing the experiences with the care to the person in a terminal process, the students felt the awakening of feelings such as anguish, sadness, insecurity and helplessness, as it is highlighted in the following statements: As a student I felt kind of tied hands, as if I could not do anything. Somehow anguished (NS05). It was my first experience and it was like, so very distressing because we spent a few days taking care of her and the days went by and she was responding well to the treatment and from one time to another she got worse and there was a despair. And I felt a bit limited to be assisting her (NS06). The experience I had was not very good, because I felt helpless in coping with the situation, not being able to reverse the condition of the patient (NS08).

The feeling of helplessness was the most striking and present in the statements: My feeling was helplessness facing that situation, because then you try to do something you want to do, only that when you get to a point that there is nothing else to be done, except to keep the comfort (NS01). My experience was bad because I felt like, incapable, as if all the care I provided was in vain, because I thought that even taking care of him, he would die and I did not have a way to avoid it. Helpless facing that situation that I could not avoid the death of that person. So I preferred to keep away, get away not to suffer with this process (NS02).

It was evident that there is a devaluation of human/relational care at the detriment of simple performance of techniques. Care is termed to this assistance part and then the student is too tied to this, he has to assist that patient, he has to provide medication, it is necessary to check the vital signs of the patient. And then he puts it aside, or infers the inter-subjectivity of the being, not observing beyond those technical procedures. Anyway, this part of care leaves much to be desired (NS02). The doctor said that there was nothing to do and left the patient the way he was. And I realized that the health professionals also did not do anything, nothing about that. All we had to do was to wait and do nothing else (NS04).

In this study, the students highlighted that during their practical classes they experienced much more the technical care, the use of technological apparatus, which tends to contribute to the difficulties in the care of the inter-subjective dimension of patients: The patient is monitored, then you start to see the pressure drop, the fall of breath, the fall of the heartbeat and you do not have anything to do because it's really time for that person to go (NS01). We become more concerned with the technique, vital signs, with the water balance of this serious patient (NS02).

\section{Category 2 - the care to the patient in a terminal process: dichotomy between theory and practice}

In this category, the existence of discrepancies between the practices of care as discussed in the classroom and how they are performed in the hospital, especially regarding the care to the person in the process of dying and death was observed, according to the following statements: I think there is a different view of this care in practice, between what is taught and what is being done ... taking care not only means you do the nursing procedures, nursing administration, but it is a whole set that should be assisting the needs of the patient not only the issue of assistance to in itself, but the care with the spirit, with the question of subjectivity of the patient (NS02). We always discussed in class, this question of humanized care, they always value that so much in theory, but it is not what we see much in practice (NS03). I think that there should be strategies in the syllabus, like how we approach these themes without considering them so strange for us and without stop treating them in a more delicate way, the best way possible so that we can provide a real treatment (NS10).

In the statement below, it is also possible to identify that in the view of students, the health professionals with more time of education, sometimes neglect care: the so discussed humanization, we do not see it in practice. Especially by part those professionals who have been working a log time. We find one that still does it that way. Maybe because of the education at home, maybe because of the religious issue as well, but we still find people who could care less. In college we study this issue of humanization well. But when get to work, it seems that things get cooler and the professionals try to justify that it is too much work and too many patients (NS03).

This study also revealed that the difficulty of 
combining the technical care to relational care, also occurs by the lack of institutional support: I felt that professionals have this difficulty because they have no institutional support. The nurses mainly, they are far distant from the care to the patient. So I think we should have a little more syllabus flexibility so that these issues could be dealt with, also the process of dying, how to handle this process with a more humanized care and not only provide that postmortem care that you do with the preparation of the body. And this is not treated in the syllabus, in the practices (NS10).

The dichotomy between theory and practice also points out that in practice, the attitudes of isolation of the seriously ill patient by the part of the health team is observed, facing the impossibility of cure, as can be described in the statements of these students: The same team, I realized that they keep away a bit and leave the person to go because it's time for the person to go away (NS01). They end up leaving the patient aside, once the patient is in a terminal process and they turn their attention to other patients. I have not witnessed at any time, this approach between the professional and the terminal patient. They provide assistance, but end up leaving the patient aside, abandoned, they don't get close to the patient, they go completely away from the patient, just waiting the time to die (NS04). I also witnessed the professionals like, providing care as if it were an obligation. As if there it was no longer a human being that was in the process of dying and death. As if it were just an object, he was dying really, the professional was providing care as an obligation (NS08).

\section{Discussion}

Dying and death are predictable and natural phenomena of life, and their monitoring, is an integral component of nursing as a profession. In most of the places of assistance to health, nurses will find patients in care at the end of life and therefore need to be prepared for this not so easy task, but necessary in the perspective of care for the control of symptoms and the promotion of quality of life for patients and their family members ${ }^{(8)}$.

This study explored the knowledge of nursing students facing the care of the person in a terminal process from their experiences in practical activities during graduation. It was evident that all the participants in this study witnessed and followed at least one situation of caring for a person in the process of dying and that evolved to death, revealing the subjectivity of their experiences with feelings of helplessness and weakness facing the confrontation of terminal situations.

Facing their experiences, the students indicated that they feel unprepared to take care of the person who is dying, demonstrating difficulties related both to the personnel unpreparedness to deal with death, as well as with the deficient theoretical and practical training to deal with the terminal process.

Researches at national and international level involving graduate students in nursing point out that there is this uncertainty of students facing the care to the patient in a terminal process. Besides highlighting that in most undergraduate courses, a small part of the syllabus is regarding the death of the patient $t^{(9,11-15)}$.

Thus, it is inferred that it is fundamentally important to widen the discussion and the professional education concerning the palliative care, improving the syllabus of the undergraduate courses in nursing with syllabus components that deal with the death and care to a person who is dying, besides thinking about developing extension activities in order to raise awareness of nursing students who discuss the issue very little ${ }^{(9)}$.

Participants of the study recognize that among the feeling that emerged when experiencing the practices of care of a person in a terminal process, helplessness was the most striking, particularly regarding the first experiences they had. They noticed that facing the situation in which no improvement occurs in the patient's condition, the procedures used by the team seem useless, resulting in feelings of incapability and frustration.

Taking care of people in the process of dying, besides being strange and frightening for those who are starting their professional practice, unveils the academic unpreparedness for the appropriate technical-scientific procedures in that situation. Even when dealing with simple attitudes in its 
implementation, such as communication with the patients or their families. Besides the difficulty in managing their feelings when engaging emotionally with the patients and their families, considering that professionals reveal a deep sense of sadness and anguish facing the loss ${ }^{(13)}$.

A little different from the Brazilian reality in which palliative care is still under development, an investigation made with nursing students from different schools in Buenos Aires in Argentina analyzed the experiences, attitudes and training that the students received regarding the care provided at the end of life and concluded that students in the country have a very positive attitude toward contact with patients in the care at the end of life, although for them, as for every human being, this relationship with patients in a situation of terminal illness and facing death is an emotionally difficult experience ${ }^{(15)}$.

In Argentina there is already a consolidated training in palliative care, but the study shows that in undergraduate courses, the syllabus component is still taught as optional and professors without specialized training in palliative care. To overcome this deficiency, a significant step would be to formally include the teaching of palliative care by trained professors and specialized training in a similar way as it has been done in many universities in Britain and the United States $^{(15)}$.

Although it is the responsibility of educational institutions of nurses to provide training with technical and scientific knowledge and skills, so that this professional can take care of the person who is dying and his family, from practices of care with sensitivity and humanism peculiar to the professional profile, those practices are still restricted to universities that offer content directed to palliative care in nursing undergraduate courses ${ }^{(9,14,16)}$.

The practices of care in health seem to suffer great influence of the "paradigm of healing," which presents a great inclination towards the care focused on technique, with overvaluation of high technology in detriment of relational care, to promote comfort, not only physical but emotional and spiritual.

This appreciation given to the technical care makes the professionals not able to see new horizons when all the possibilities of use of the technological apparatus are finished. When the impossibilities of use of such apparatus is detected, the students perceived a change of attitude by part of the health team, passing by a posture of isolation of patients with no chance of cure, although this is the moment in which the patient and family most need the health team in rendering a care of attention, zeal and respect to the process of loss.

It is important to remember that health professionals, especially the nursing team, due to their closer proximity to the patient and their family members, have responsibility in family preparation for the prognosis of their loved one, often unsatisfactory ${ }^{(12)}$. In this preparation measures of comfort for a death with dignity should promoted and a satisfactory process of grieving.

The devaluation of care, while attention to the multidimensional needs of the person, based on the completeness of the being, is very present in the context of health services. This devaluation has contributed for the students not to understand that their education is at the service of life and that death is part of it. In this perspective, the health professional should both feel accomplished by providing care and by restoring life to the person, as well as feeling accomplishment by providing a dignified death, according to what is recommended by the philosophy of palliative care ${ }^{(2,5)}$.

It is inferred that in practice as observed by the students, the care provided by the health team, is restricted to maintenance of life and to the control and monitoring of heart beat, blood pressure and respiratory movements and this is a major condition for the one who is dealing with situations of irreversible death. Therefore, there should be a rationalization on the care provided by the health team, between the desire to maintain life at in any costs and the inevitability of death. This attitude of 
inexorability facing death, not knowing and accepting it as part of life is what leads the students and future health professionals to express these negative feelings of helplessness in the process of dying and death ${ }^{(2,9,16)}$.

One cannot overlook the importance that the technical care has, it is indispensable for the maintenance of life with quality, minimizing suffering and favoring physical restoring. However, the overvaluation of this dimension of care, can alienate the nurse both concerning intuitiveness and the necessary investment for a care with biological aspects, leading to neglect the interpersonal aspects ${ }^{(6)}$.

Nursing students and future professionals need to acquire a professional education that directs them to a comprehensive care, seeing the person as a bio-psycho-social-spiritual and cultural being, from the development of skills and abilities in relation to emotional and ethical aspects so that in their education, besides performing the techniques competently and safely, know how to deal with their feelings and emotions, enabling the care of the other at all stages of life, from birth to death, considering death a natural process ${ }^{(5,7)}$.

Regarding the dichotomy between theory and practice in the care to the patient in a terminal process, according to what was previously mentioned, there is the possibility of the existence of practical unpreparedness by part of the health professionals in dealing with issues related to death, and such fact is already perceived since graduation ${ }^{(9,16)}$.

The experiences of health professionals facing the physical suffering, particularly pain, can bring the sense of failure, helplessness and guilt, causing conflicting attitudes in the development of the assistance to be provided to the patient. Some propose to maintain life at any cost, choosing dysthanasia processes, others keep away from the patient promoting even unconsciously, social isolation, because they understand that if there is no possibility of cure, nothing more can be done $\mathrm{e}^{(2,12)}$.

Thus, the fact that the dichotomy between life and death, very present in the discourses and practices in the everyday life of the nursing professionals, generates feelings that are enhanced by the interdict that death causes. This existential dilemma arises from the negative valuing assigned to the human being who is in a process of finitude, once the actions of health provides overemphasis to life, while the failure of the work of the health team is attributed to death ${ }^{(7)}$.

Thus, the participants of this study showed that the care practices developed in the daily life of the nurses and their team differ from discussions undertaken in the academic environment, denying the discourse that the professional must always be besides the patient, regardless of the condition of health or disease in which he is.

The traditional teaching model is the generator of dichotomy between theory and practice because the practice is elaborated in a way that many times does not favor the continuation of the discussions initiated during the undergraduate course ${ }^{(17)}$.

Although they have been taught the importance of proximity and physical and emotional support to the patient, it is something quite different from what was observed by the students in the everyday activities of the health professionals, so that they end up keeping away from the patients. And when it comes to patient with no chance of cure, this practice of isolation is worsened.

When analyzing the existence of possible correlation between the professional profile of professors and their preparation to approach the issue on terminal illness in nursing graduation, it was evident that there is a distancing of the nursing team towards the patient at the time of death, many times indirectly, denying support and sympathy with the mourning family, concluding that in fact there is a lack of preparation of health professionals and professors, for the care to the one who is dying, hindering a practice of a more human care which can provide the minimum of dignity to the person who is dying and to his family ${ }^{(18)}$.

Social isolation of the seriously ill patient by the health team, emerges from the impossibility of 
cure aimed. The professionals have difficulties in facing death as something natural, once they believe that the occurrence of death is the result of a failed professional activity. Thus, the patient is abandoned in the emptiness of assistance and relation, and the team turns their care to those who are clearly more likely to survive ${ }^{(19)}$.

The attitude of isolation caused by the imminence of death comes from the inability or lack of preparation of the professionals to offer possibilities of assistance beyond the technical care, such as active listening, dialogue on issues related to terminal illness and the settlement of unresolved issues, when the nursing team can develop the role of intermediary between the patient, family and other health professionals, considering their privileged condition to spend most of the time next to the patient in a closer contact with the family. Such possibilities avoid limiting care to only one assistance directed by technological support and the control of physical symptoms and signs, as a reflex of the impacting reactions that death brings, and they are enhanced by its interdict ${ }^{(18)}$.

Another aspect observed in the statements of the participants is the care rendered to a terminal patient, who do not represent the essence of what nursing care is ${ }^{(7)}$, directed by attention and appreciation of the multidimensionality of the patients and their families with scientific basis, but it represents careless attitudes as highlighted by the participants. The hyper technicality, the passivity of the health professional facing the situation of imminent death, the coldness, the indifference, the lack of information to the patient and his family, about the evolution of the clinical picture and the lack of communication between the health team and the family of the patient were some situations considered as carelessness by the participants.

With the day-to-day professional practice, it is clear that the nursing team is increasingly moving away from the focus of their actions, that is, from the care grounded in a multidimensional approach. This care should differ from the ordinary care and be guided by a humanistic and scientific knowledge, enabling the development of the professional, concerning relation and interpersonal competences, with knowledge acquired and culturally seized, knowing how to use the techniques to help patients, families and the community in the recovery of the health of the patient or to provide a dignified death ${ }^{(7,12,18)}$.

Considering in this perspective of a human care to the person in a terminal process and his family, there is the need of palliative care as a philosophy in which the comprehensive care to the person is turned to the need of a humanistic approach with an emphasis in the quality of life, provided to patients and their families, valuing the human being in its bio-psycho-social-spiritual dimensions. Beyond the control and relief of physical and psychological pain, the palliative care provide an approach about the ethical issues that permeate the human care, involving the need for communication as a therapeutic measure and the establishment of positive links and finally, emphasizing the subjectivity of the being and the aspects involving spirituality and preparation for mourning $^{(6)}$.

Understanding the needs of the ones who are dying and involving their families in this process are indispensable human attitudes when it comes to a humanistic approach in favor of a death with dignity. In this regard, the need of a practice of humanized care provided by the nursing team as part of the palliative care to the patient in a terminal process is emphasized.

\section{Conclusion}

The study allowed us to understand how the participants of the interviews realize the various feelings that emerge facing the inevitability of death, especially when it refers to the negative feelings when the students are faced with terminal situations in their activities of practices and training. In addition, there is a clear disproportion between the humanistic 
approach and the therapeutic technicality, with a prevalence of the latter at the expense of humanistic aspects inherent to care, according to the perception of the students. This reality strengthens the dichotomy between theory and practice as well as shows that students are still unprepared to face the process of dying and death.

Thus, although death is a constant and present phenomenon in the everyday life of the nursing team, it can be seen, through the statements of the students, that the university does not provide the necessary moments of discussions on the theme death and dying, and that students are still are unprepared to provide care to terminal patients.

Providing physical, emotional comfort and relieving the patient's pain, were practices of care which appeared frequently in the interviews, although, not as something that should be offered to the terminal patient but to provide a dignified death, but as a condition that is not valued by part of the nursing team, demonstrating that the technical care still prevails in detriment of humanistic and sensitive care.

Besides that, the perplexity of the students facing the situations of absence of the nursing team was observed, culminating in the isolation of the patient in the process of dying and death, showing that nursing professionals still do not feel prepared to deal with terminality as well as the care of the person who is dying.

Thus, it is considered that the objective was achieved because it was possible to know the impressions of nursing students facing the care to the patient in a process of dying and death and it is expected that changes in the syllabus of the graduation courses are discussed, with the inclusion of syllabus components concerning palliative care, taught by trained professors, enabling the students to recognize their weaknesses facing the death of those under their care and reflect on aspects involving human multidimensionality and so understand that caring goes far beyond healing.

It is opportune to highlight as limitation of the study, the reality of only one educational institution and the reduced number of students and it cannot allow generalizations. But it is taught that it is possible to contribute to enhance knowledge and reflection on that theme.

\section{Acknowledgments}

We thank the Pró-Reitoria de Extensão of the Universidade Federal da Bahia and the Conselho Nacional de Desenvolvimento Científico e Tecnológico, for their financial support.

\section{Collaborations}

Silva RS and Oliveira CCSG contributed for the conception, field data collection, analysis, interpretation of the data, writing of the article and the final approval of the version to be published. Pereira A and Amaral JB contributed to the conception and the final approval of the version to be published.

\section{References}

1. Santos MA, Hormanez M. Atitude frente à morte em profissionais e estudantes de enfermagem: revisão da produção científica da última década. Cienc Saúde Coletiva. 2013; 18(9):2757-68.

2. Kovács MJ. Sofrimento da equipe de saúde no contexto hospitalar: cuidando do cuidador profissional. Mundo Saúde. 2010; 34(4):420-9.

3. Ariès P. História da morte no ocidente. Rio de Janeiro: Ediouro; 2003.

4. Dolina JV, Bellato R, Araújo LFS. Research experience with a person going through the process of dying and death. J Palliat Med. 2014; 17(2):244-5.

5. Vargas D. Death and dying: feelings and behaviors of nursing students. Acta Paul Enferm. 2010; 23(3):404-10. 
6. Silva RS, Silva MJP. Enfermagem e os cuidados paliativos. In: Silva RS, Amaral JB, Malagutti W. Enfermagem em cuidados paliativos: cuidando para uma boa morte. São Paulo: Martinari; 2013. p. 3-35.

7. Silva RS, Campos ARC, Pereira A. Caring for the patient in the process of dying at the Intensive Care Unit. Rev Esc Enferm USP. 2011; 45(3):73844.

8. Ek K, Westin L, Prahl C, Österlind J, Strang S, Bergh I, et al. Death and caring for dying patients: exploring first-year nursing students' descriptive experiences. Int J Palliat Nurs. 2014; 20(10):50915.

9. Benedetti GMS, Oliveira K, Oliveira WT, Sales CA, Ferreira PC. Meaning of the death/dying process for entering nursing students. Rev Gaúcha Enferm. 2013; 34(1):173-9.

10. Bardin L. Análise de conteúdo. 3a ed. Lisboa: Edições 70; 2011.

11. Sadala MLA, Silva FM. Taking care of terminal patients: nursing student's perspective. Rev Esc Enferm USP. 2009; 43(2):287-94.

12. Pereira A, Campos ARC, Silva RS. Death with dignity: nurse's feelings who are caring for patients who are dying in intensive care unit. Rev Enferm UFPE [periódico na Internet] 2009 [cited 2015 Mar. 2]; 3(3):131-6. Available from: http:// www.revista.ufpe.br/revistaenfermagem/index. php/revista/article/view/165/pdf_906
13. Whitehe PB, Anderson ES, Redican KJ, Stratton R. Studying the effects of the end-of-life nursing education consortium at the institutional level. J Hosp Palliat Nurs. 2010; 12(3):184-93.

14. Sales CA, Ferreira PC, Silva VA, Oliveira WT, Marcon SS. The death and dying process: definitions of nursing undergraduate students. Rev Rene. 2013; 14(3):521-30.

15. Mutto EM, Errázquin A, Rabhansl MM, Villar MJ. Nursing education: the experience, attitudes, and impact of caring for dying patients by undergraduate Argentinian nursing students. J Palliat Med. 2010; 13(12):1445-50.

16. Cantídio FS, Vieira MA, Sena RR. Significado da morte e de morrer para os alunos de enfermagem. Invest Educ Enferm. 2011; 29(3):407-18.

17. Berardinelli LMM, Martins AMF, Clos AC, Santos I, Santos MLSC, Correia LM. Concepções de cuidado na perspectiva de residentes de enfermagem: os nexos entre prática e teoria. Rev Enferm UERJ. 2012; 20 (n.esp.1):567-72.

18. Bandeira D, Cogo SB, Hildebrandt LM, Badke MR. Death and dying in the formation process of nurses from the perspective of nursing professors. Texto Contexto Enferm. 2014; 23(2):400-7.

19. Menezes RA, Barbosa PC. A construção da "boa morte" em diferentes etapas da vida: reflexões em torno do ideário paliativista para adultos e crianças. Cienc Saúde Coletiva. 2013; 18(9):265362. 